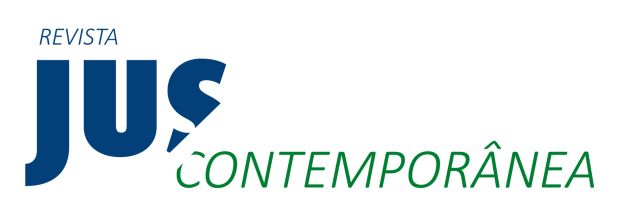

ARTIGO

https://doi.org/10.30749/2674-9734.v2n0a351

\title{
PODER DE POLÍCIA E A IMPOSSIBILIDADE DE DELEGAÇÃO AO PARTICULAR
}

\section{POLICE POWER AND THE IMPOSSIBILITY OF DELEGATION TO PRIVATE INDIVIDUALS}

\author{
Magelo dos Reis ${ }^{1}$ \\ Fabiana Silva Delgado ${ }^{2}$
}

Resumo: O trabalho analisa o instituto Poder de Polícia que é uma das atribuições do Estado, e que tem sido alvo de discussões e contestações no decorrer dos anos no tocante a sua impossibilidade de delegação ao particular. Argumentou-se que o poder de polícia pode ser delegado a particulares. Nesse sentido, o Senador Antonio Anastasia apresentou em 17 de agosto de 2017 um Projeto de Lei (PLS 280/2017) que define diretrizes e requisitos para a delegação do serviço público de fiscalização administrativa a particulares. O método a ser utilizado será o descritivo e contará com um levantamento bibliográfico, onde serão analisados livros, artigos, Legislação e Jurisprudência.

Palavras-chave: Direito Administrativo. Poder de polícia. Delegação. Impossibilidade.

Abstract: This paper analyzed the power of police that is one of the attributions of the State and that has been the subject of discussions, objections over the years and its impossibility of delegation to the individual. The argument then arose that police power could be delegated to private individuals. Following this, Senator Antonio Anastasia presented on August 17, 2017, a Bill (PLS 280/2017) that defines guidelines and requirements for the delegation of the public service of administrative supervision to individuals. The method to be used will be descriptive and will have a bibliographic survey, where books, articles, Legislation and Jurisprudence will be analyzed.

Keywords: Administrative law. Police power. Delegation. Impossibility.

Recebido em: 15/05/2020

Aceito para publicação em: 15/05/2020

\footnotetext{
${ }^{1}$ Possui graduação em Direito.

${ }^{2}$ Possui graduação em Direito pela Universidade Federal do Rio de Janeiro. Ex- aluna da Escola da Magistratura do Estado do Rio de Janeiro. Mestranda no PPGDL do Centro Universitário Augusto Motta (UNISUAM).
} 


\section{INTRODUÇÃO}

O poder de polícia é uma função do Estado que tem sido questionado ao longo do tempo. Trata-se de um assunto complexo e que requer uma análise criteriosa na busca de compreender o pensamento das diversas correntes doutrinárias. Além disso, é um tema que vive em constante mudança.

O poder da polícia inicialmente era mitigado em decorrência do Estado mínimo, desprendido na economia. Tal fato era fruto da exigência de limites negativos à liberdade e à propriedade, condição para a coexistência de direitos. A primeira mudança do poder de polícia ocorreu com a crise econômica em 1929 e a partir daí se fortaleceu o sentido intervencionista do Estado.

Os atributos do poder de polícia estão ligados às concepções históricas de cada sociedade, podendo haver particularidades entre algumas e divergências entre outras.

Após muitas mudanças, o tema norteador afigura-se como questionamento, até que ponto o poder de polícia preserva seu conteúdo original e quais as alterações que têm ocorrido no direito brasileiro a ponto de delegar poder ao particular.

Diante do exposto, o objetivo do presente estudo é analisar o poder de polícia e a possibilidade do exercício pelo particular. Para isto, serão analisados livros e artigos, buscando um fundamento bibliográfico com relação a esta temática.

A escolha por esse tema deu-se ao fato de que, buscando potencializar o serviço público, o Senador Antônio Anastasia apresentou em 17 de agosto de 2017 um Projeto de Lei, PLS 280/2017 (BRASIL, 2017), que define diretrizes e requisitos para a delegação do serviço público de fiscalização administrativa a particulares, ato considerado exclusivo do ente público.

Neste sentido, manifestou-se o Excelentíssimo senador, em sua página virtual sobre o mencionado projeto:

Na prática, a proposta vai possibilitar que a Administração Pública possa contar com parcerias privadas para exercer o poder de fiscalização nos mais diversos setores estatais. Para cada setor que o poder público prever a delegação será necessária lei específica. (ASSESSORIA DE IMPRENSA DO SENADOR ANTONIO ANASTASIA, 2017). 


\section{PODER DE POLÍCIA NO DIREITO BRASILEIRO}

O poder de polícia, que nos conceitua a literatura clássica de Carvalho Filho (2019, p. 171), fala a respeito da atividade estatal que implica em limitações do exercício dos direitos individuais em benefício da segurança:

O poder de polícia como a prerrogativa de direito público que, calcada na lei, autoriza a Administração Pública a restringir o uso e o gozo da liberdade e da propriedade em favor do interesse da coletividade".

Buscando na literatura moderna, Di Pietro (2019, p. 320) tem conceituado que no direito brasileiro: "O poder de polícia diz respeito á atividade do Estado que limita o exercício dos direitos individuais em benefício do interesse público".

Neste sentido, também as palavras de Meirelles e Burle Filho, que defendem que a Administração pública tem a faculdade para condicionar, restringir o uso e gozo de bens: "Poder de polícia é a faculdade de que dispõe a Administração Pública para condicionar e restringir o uso e gozo de bens, atividades e direitos individuais, em benefício da coletividade ou do próprio Estado." (MEIRELLES; BURLE FILHO, 2016, p. 151).

O poder de polícia pode ser observado conforme alguns autores sobre o prisma de duas óticas: sentido amplo e sentido restrito. Vejamos o que nos diz Rossi (2019, p. 198):

Poder de polícia em sentido amplo: engloba toda e qualquer ação restritiva do Estado em relação aos direitos individuais, abarcando atos do Executivo e do Legislativo, nos termos do art. 50, II, da Constituição: "Ninguém será obrigado a fazer ou deixar de fazer alguma coisa senão em virtude de lei".

Poder de polícia em sentido restrito: é a atividade administrativa exercida pelos agentes da Administração no sentido de restringir e condicionar a liberdade e a propriedade dos indivíduos em nome do interesse público. Abarca apenas e tão somente os atos do Executivo, isto é, os atos tipicamente administrativos. Nesse sentido, já pressupomos preexistência de lei para que os administradores imponham a disciplina e as restrições aos direitos dos indivíduos. 
Trazendo um jeito diferente de analisar o poder de polícia, Oliveira (2018, p. 269) conceitua os dois sentidos da seguinte maneira:

O poder de polícia possui dois sentidos distintos:

Sentido amplo: o poder polícia compreende toda e qualquer atuação restritiva à liberdade e a propriedade que tem por objetivo a satisfação de necessidades coletivas. De acordo com essa concepção, o poder de polícia envolve tanto a atividade legislativa, que inova na ordem jurídica com a criação de direitos e obrigações para as pessoas, quanto a atividade administrativa, que executa os termos da lei;

Sentido restrito: o poder de polícia significa o exercício da função administrativa, fundada na lei, que restringe e condiciona o exercício de direitos e atividades privadas, com o objetivo de implementar o interesse público. Nesse sentido, a polícia administrativa relaciona-se diretamente à função administrativa.

Já no Código Tributário Nacional (CTN) o conceito de poder de polícia decorre do fato de constituir o exercício desse poder um dos fatos geradores da taxa, conforme art. 145, II, da Constituição Federal (BRASIL, 1988) e art. 77 do referido Código (BRASIL, 1966).

O artigo 145, II, da Constituição Federal de 88 traz esta definição legal:

Art. 145. A União, os Estados, o Distrito Federal e os Municípios poderão instituir os seguintes tributos:

II - taxas, em razão do exercício do poder de polícia ou pela utilização, efetiva ou potencial, de serviços públicos específicos e divisíveis, prestados ao contribuinte ou postos a sua disposição. (BRASIL, 1988).

O artigo 77 do CTN define as taxas que tem como fato gerador o poder de polícia.

Art. 77. As taxas cobradas pela União, pelos Estados, pelo Distrito Federal ou pelos Municípios, no âmbito de suas respectivas atribuições, têm como fato gerador o exercício regular do poder de polícia, ou a utilização, efetiva ou potencial, de serviço público específico e divisível, prestado ao contribuinte ou posto à sua disposição. (BRASIL, 1966).

Note-se que o artigo 78 do CTN define o poder de polícia como atividade da administração pública; mas no parágrafo único considera regular o seu exercício "quando desempenhado pelo órgão competente nos limites da lei aplicável, com 
observância do processo legal e, tratando-se de atividade que a lei tenha como discricionária, sem abuso ou desvio de poder". (DI PIETRO, 2019, p. 320).

$\mathrm{O}$ art. 78 do CTN traz uma definição legal do poder de polícia:

Art. 78. Considera-se poder de polícia a atividade da administração pública que, limitando ou disciplinando direito, interesse ou liberdade, regula a prática de ato ou a abstenção de fato, em razão de interesse público concernente à segurança, à higiene, à ordem, aos costumes, à disciplina da produção e do mercado, ao exercício de atividades econômicas dependentes de concessão ou autorização do Poder Público, à tranquilidade pública ou ao respeito à propriedade e aos direitos individuais ou coletivos.

Parágrafo único: Considera-se regular o exercício do poder de polícia quando desempenhado pelo órgão competente nos limites da lei aplicável, com observância do processo legal e, tratando-se atividade que a lei tenha como discricionária, sem abuso ou desvio de poder. (BRASIL, 1966).

O Poder de Polícia busca também condicionar e restringir o uso de bens, atividades e direitos individuais em benefício da coletividade e do próprio Estado. (DI PIETRO, 2019, p. 332).

Historicamente não havia sentido falar em um Direito Administrativo durante a Idade Média, período característico do Estado Absolutista, em que inexistiam regras jurídicas colocadas acima da vontade dos monarcas. Foi somente após a Revolução Francesa, em 1789, que o fortalecimento dos Parlamentos criou condições para estabelecerem-se regras limitadoras da atuação da administração pública. Ocorrida pouco antes da Revolução Francesa, no mesmo século XVIII, tem sido também apontada pelos estudiosos como decisiva para o nascimento da ideia de um Direito Administrativo, a publicação da obra O espírito das leis (L'esprit des lois, 1748), de Charles-Louis de Secondat, ou Charles de Montesquieu, mais conhecido como Barão de Montesquieu. (MAZZA, 2019, p. 70).

É importante apontar que foi no início do século XVIII que a polícia passou a responder à atividade pública interna. A partir deste momento é dado o sentido amplo de polícia, que passa a ter como noção de Administração Pública. (DI PIETRO, 2010, p. 116).

Ao exercer o poder de polícia, o agente público percorre determinado ciclo até a aplicação da sanção, também chamado ciclo de polícia. 
Diogo de Figueiredo Moreira Neto (2005), em seu Curso de Direito Administrativo, estruturou este ciclo do poder de polícia em quatro fases. São elas: ordem de polícia, consentimento de polícia, fiscalização de polícia e sansão de polícia.

A primeira fase (ordem de polícia) é aquele preceito legal no qual é dada validade à limitação prevista, para que não se pratique ato que lesione o interesse público ou se omita ao deixar de fazer algo que evite a lesão ao interesse público. Como exemplos desse preceito legal, pode-se mencionar a vedação de autorização de porte de arma de fogo de uso restrito às Forças Armadas, e outra em que a vedação existe de início, mas é possível, após a devida avaliação, que a Administração dê o consentimento para o exercício de determinada atividade ou o uso de certa propriedade privada como é o caso da licença para construir, caso fique demonstrado que o projeto atende à legislação específica.

A segunda fase (consentimento de polícia) é o ato administrativo que confere anuência ao exercício de atividade ou ao uso de propriedade e somente existe se for a segunda espécie de ordem de polícia ("preceito negativo com reserva de consentimento").

A terceira fase (fiscalização de polícia) é a verificação se as ordens de polícia estão sendo cumpridas (se não está sendo exercida uma atividade vedada ou se uma atividade consentida está sendo executada dentro dos limites estabelecidos).

A quarta fase (sanção de polícia) é a fase em que, verificada afronta à ordem de polícia, é aplicada a pena de polícia. (MOREIRA NETO, 2005, p. 395-404).

\subsection{Atributos do poder de polícia}

Para que o Estado atue de forma decisiva, permanente, e seja possível a efetivação do poder de polícia da administração, esse poder deve possuir certos atributos que são: discricionariedade, autoexecutoriedade e coercibilidade.

\subsubsection{Discricionariedade}

A discricionariedade se faz na livre escolha pela Administração pública, da oportunidade e conveniência para o exercício do poder de polícia:

A discricionariedade, como já vimos, traduz-se na livre escolha, pela Administração, da oportunidade e conveniência de exercer o poder de polícia, bem como de aplicar as sanções e empregar os meios conducentes a atingir o fim colimado, que é a proteção de algum interesse público. Neste particular, e desde que 0 ato de polícia administrativa se contenha nos limites legais e a autoridade se mantenha na faixa de opção que the é 
atribuída, a discricionariedade é legítima. (MEIRELLES; BURLE FILHO, 2016, p. 159).

Eduardo Antunes de Oliveira diz que geralmente as normas que conferem poderes discricionários não determinam a forma e as condições para que se execute o ato, de tal modo que a administração pública tem a autonomia para estabelecer as condições para o exercício de um determinado ato. Esse geralmente é o centro de discricionariedade, que como podemos ver não é total e é reflexo do que está disposto na lei. (OLIVEIRA, 2012).

Maria Sylvia Zanella Di Pietro diz que a discricionariedade mesmo estando presente na maior parte das medidas de polícia, nem sempre isso ocorre.

\begin{abstract}
Quanto à discricionariedade, embora esteja presente na maior parte das medidas de polícia, nem sempre isso ocorre. Às vezes, a lei deixa certa margem de liberdade de apreciação quanto a determinados elementos, como o motivo ou o objeto, mesmo porque ao legislador não é dado prever todas as hipóteses possíveis a exigir a atuação de polícia. Assim, em grande parte dos casos concretos, a Administração terá que decidir qual o melhor momento de agir, qual o meio de ação mais adequado, qual a sanção cabível diante das previstas na norma legal. Em tais circunstâncias, o poder de polícia será discricionário. (DI PIETRO, 2010, p. 324).
\end{abstract}

Carvalho Filho nos diz que quando a Administração tem a lei ao seu lado, pode considerar a área de atividade às restrições em favor do interesse público.

Quando tem a lei diante de si, a Administração pode levar em consideração a área de atividade em que vai impor a restrição em favor do interesse público e, depois de escolhê-la, o conteúdo e a dimensão das limitações. É o caso, por exemplo, em que autoridades públicas enumeram apenas alguns rios onde a pesca se tornará proibida. Sem dúvida que nesse momento a Administração age no exercício de seu poder discricionário. (CARVALHO FILHO, 2019, p. 184).

Meirelles e Burle Filho afirmam que não podemos confundir discricionariedade com arbitrariedade, devemos nos ater a critérios legais, legítimos e válidos.

Discricionariedade não se confunde com arbitrariedade. Discricionariedade é liberdade de agir dentro dos limites legais; arbitrariedade é ação fora ou excedente da lei, com abuso ou desvio de poder. $\mathrm{O}$ ato discricionário, quando se atém aos critérios legais, é legítimo e 
válido; o ato arbitrário é sempre ilegítimo e inválido. (MEIRELLES; BURLE FILHO, 2016, p. 159).

\title{
2.1.2 Autoexecutoriedade
}

Na Autoexecutoriedade devemos observar os princípios da eficiência e da supremacia do interesse público sobre o particular, vejamos o que nos diz Licínia Rossi:

\begin{abstract}
Autoexecutoriedade significa que a Administração Pública, até como observância ao princípio da eficiência e da supremacia do interesse público sobre o particular, realiza os seus atos independentemente da presença e autorização do Judiciário.

A Administração Pública promove imediatamente, por seus próprios meios (humanos e materiais) a submissão integral do administrado àquelas determinações editadas, sem necessidade de recorrer a qualquer outro Poder para isso. Quando apreende bens impróprios e nocivos ao consumo da população, ou ainda quando interdita estabelecimentos poluentes da atmosfera, o faz como consequência do atributo da autoexecutoriedade. (ROSSI, 2019, p. 211).
\end{abstract}

Nas palavras de Maria Sylvia Zanella Di Pietro (2010, p. 325) a autoexecutoriedade é a possibilidade que a Administração tem de por em execução suas decisões, vejamos: "A autoexecutoriedade (que os franceses chamam de executoriedade apenas) é a possibilidade que tem a Administração de, com os próprios meios, pôr em execução as suas decisões, sem precisar recorrer previamente ao Poder Judiciário".

Para Maria Sylvia Zanella Di Pietro a autoexecutoriedade pode ser dividida em dois: exigibilidade e executoriedade. No tocante à exigibilidade ela assim leciona.

Resulta da possibilidade que tem a Administração de tomar decisões executórias, ou seja, decisões que dispensam a Administração de dirigir-se preliminarmente ao juiz para impor a obrigação ao administrado. A decisão administrativa impõe-se ao particular ainda contra a sua concordância; se este quiser se opor, terá que ir a juízo.

(DI PIETRO, 2010, p. 325).

Em sua dissertação Leonardo de Mello Gonçalves (2010) afirma que no direito brasileiro a executoriedade ou autoexecutoriedade, é o atributo do ato administrativo que lhe outorga meios para exercer de forma direta a coação, o que é 
importante relatar que a administração pública pode, por seus próprios meios, aplicá-los, sem que se tenha a necessidade de uma autorização judicial prévia.

Conforme asseveram Meirelles e Burle Filho (2016, p. 160), pedir uma autorização do Poder Judiciário é negar-se o próprio poder de polícia, vejamos: "Exigir-se prévia autorização do Poder Judiciário equivale a negar-se o próprio poder de polícia administrativa, cujo ato tem de ser sumário, direto e imediato, sem as delongas e complicações de um processo judiciário prévio".

\subsubsection{Coercibilidade}

Sempre em que se constituir uma obrigação ao administrado, aparece o atributo da coercibilidade, assim nos diz Rossi (2019, p. 212):

$O$ atributo da coercibilidade aparece sempre que 0 ato constituir uma obrigação ao administrado. Decorre da imperatividade dos atos administrativos assim como do ius imperii estatal, corolário do princípio da supremacia do interesse público sobre o particular, no sentido de obrigar todos a observarem os comandos ditados pelo Estado.

Nas palavras de Carvalho Filho, quando houver uma resistência contra a Administração Pública, ela pode usar a força.

Diga-se, por oportuno, que é intrínseco a essa característica o poder que tem a Administração de usar a força, caso necessária para vencer eventual recalcitrância. É o que sucede, por exemplo, quando, em regime de greve, operários se apoderam manu militari da fábrica e se recusam a desocupá-la na forma da lei. (CARVALHO FILHO, 2019, p. 187).

A coercibilidade, conforme apontam as doutrinas, é o atributo do poder de polícia que dá respaldo ao uso da "Violência", quando houver por parte do particular resistência. Tal violência deve ser proporcional. $\mathrm{O}$ uso da violência desproporcional torna o ato arbitrário e ilegal, respondendo o agente cível e criminalmente. Neste sentido:

A violência desnecessária ou desproporcional à resistência, que em tal caso pode caracterizar o excesso de poder e o abuso de autoridade nulificadores do ato praticado e ensejadores das ações civis e criminais para reparação do dano e punição dos culpados. (MEIRELLES; BURLE FILHO, 2016, p. 161). 


\section{POSICIONAMENTO DOS TRIBUNAIS QUANTO À DELEGAÇÃO DO PODER DE POLÍCIA}

Ante o princípio de "quem pode o mais pode o menos", não é difícil atribuir às pessoas políticas da federação o exercício do poder de polícia. Afinal, se thes incumbe editar as próprias leis limitativas, coerente que Ihes confira, em decorrência, o poder de minudenciar as restrições. Trata-se aqui do poder de polícia originário, que alcança, em sentido amplo, as leis e os atos administrativos provenientes de tais pessoas. Nesse sentido:

O Estado, porém, não age somente por seus agentes e órgãos internos. Várias atividades administrativas e serviços públicos são executados por pessoas administrativas vinculadas ao Estado. A dúvida consiste em saber se tais pessoas têm idoneidade para exercer o poder de polícia. $\mathrm{E}$ a resposta não pode deixar de ser positiva, conforme proclama a doutrina mais autorizada. Tais entidades, com efeito, são o prolongamento do Estado e recebem deste o suporte jurídico para o desempenho, por delegação, de funções públicas a ele cometidas. Indispensável, todavia, para a validade dessa atuação é que a delegação seja feita por lei formal, originária da função regular do Legislativo. Observe-se que a existência da lei é o pressuposto de validade da polícia administrativa exercida pela própria Administração Direta e, desse modo, nada obstaria que servisse também como respaldo da atuação de entidades paraestatais, mesmo que sejam elas dotadas de personalidade jurídica de direito privado. O que importa, repita-se, é que haja expressa delegação na lei pertinente e que o delegatário seja entidade integrante da Administração Pública. (CARVALHO FILHO, 2019, p. 175).

Rafael Carvalho Rezende Oliveira aponta em seu livro que a delegação do poder de polícia depende do preenchimento de três requisitos, a saber:

a) A delegação deve ser feita por lei, não se admitindo via contratual;

b) Apenas a fiscalização do poder de polícia pode ser delegada;

c) As entidades privadas delegatárias devem integrar a Administração Indireta (empresas públicas, sociedade de economia mista e fundação estatais de direito privado), não sendo lícita a delegação às entidades privadas em geral. Nesse sentido, José dos Santos Carvalho Filho. (OLIVEIRA, 2018, p. 283).

O Superior Tribunal Federal já se manifestou sobre a impossibilidade de delegação ao particular o exercício do poder de polícia, na qual argumentou que é 
indelegável ao particular a atividade típica de Estado, conforme nos diz Rafael Oliveira.

O STF tem afirmado a impossibilidade genérica de exercício do poder de polícia por particulares. Foi o que ocorreu quando a Suprema Corte declarou a inconstitucionalidade do artigo 58 da lei 9.649/1998, que pretendia estabelecer 0 exercício dos serviços de fiscalização das profissões regulamentadas por entidades privadas, delegatárias do poder público. 0 argumento utilizado pela suprema corte foi no sentido de ser indelegável aos particulares a atividade típica de Estado (poder de polícia). Curiosamente, o STF, posteriormente, afirmou que a Ordem dos Advogados do Brasil (OAB), que também exerce fiscalização de profissões, não integraria a Administração Pública Indireta, sendo certe que a sua atividade não difere essencialmente daquelas desenvolvidas pelos demais Conselhos profissionais. Contudo, a Suprema Corte, em hipótese de repercussão geral, afirmou que as ações que envolvem a OAB devem ser julgadas pela justiça Federal, em razão da natureza autárquica desta entidade. (OLIVEIRA, 2018, p. 283)

Corroborando com a Suprema Corte vejamos o que diz Carvalho Filho (2019,

p. 177):

Cabe destacar que a delegação não pode ser outorgada a pessoas da iniciativa privada, desprovidas de vinculação oficial com os entes públicos, visto que, por maior que seja a parceria que tenham com estes, jamais serão dotadas da potestade (ius imperii) necessária ao desempenho da atividade de polícia.

Mazza (2019, p. 666) também entende que é indelegável:

O poder de polícia é manifestação do poder de império (ius imperii) do Estado, pressupondo a posição de superioridade de quem o exerce, em relação ao administrado (art. 40, III, da Lei n. 11.079/2004). Por isso, a doutrina não admite delegação do exercício do poder de polícia a particulares. Segundo entendimento do Supremo Tribunal Federal, poder de polícia só pode ser delegado a pessoas jurídicas de direito público, e não a pessoas jurídicas de direito privado (ADIn 1.717-6). (STF, 2002, apud MAZZA, 2019, p. 666).

Conforme assevera Carvalho Filho (2019), no que se trata à possibilidade da delegação do exercício do poder de polícia por particulares, cabe apontar que esta questão já foi apreciada e discutida pelo Supremo Tribunal Federal (STF) na Ação

Direta de Inconstitucionalidade 1.717, na qual a Corte entendeu não ser possível esta 
delegação, ou seja, não é permitido transferir o exercício do poder de polícia para pessoas jurídicas que não integram a Administração Pública.

O julgado acima justifica-se pelo fato de o Estado deter o monopólio da violência, de modo que não pode ser transferido a particulares. Legalmente, somente o Estado pode fazer uso de força para fazer cumprir os preceitos legais; no entanto, aos particulares não há vedação total sobre o exercício do poder de polícia, o que resulta em algumas atividades acessórias que podem ser delegadas. (JUSTEN FILHO, 2014).

O Ministro Marco Aurélio, relator na matéria que consta do Recurso Extraordinário (RE) 637.539, que trata da aplicação de multas de trânsito por guardas municipais, um tema com repercussão geral reconhecida pelo STF. Segundo o Ministro Marco Aurélio (BRASIL, 2011):

O tema, de índole constitucional, está a merecer o crivo do Supremo. Tal recurso foi proposto pelo Município do Rio de Janeiro contra decisão do Tribunal de Justiça do Estado do Rio de Janeiro (TJERJ), que considerou não ser atribuição da guarda municipal a aplicação de multa de trânsito, tendo em vista o disposto no artigo $144, \S 80$, da Constituição da República Federativa do Brasil - CRFB. A questão é que para o TJERJ, os municípios não têm poder de polícia de segurança pública e, por conseguinte, as autuações de trânsito lavradas pelos guardas municipais cariocas são nulas de pleno direito. O município enfatiza também a importância do pronunciamento do STF sobre a questão nos âmbitos social, político e jurídico, "haja vista estar em jogo a autonomia municipal e a possibilidade de desautorizar-se a polícia de trânsito local e, com isso, permitir-se a impunidade de um sem-número de motoristas." Diante dessa questão debatida neste recurso, o Ministro Marco Aurélio acredita que trata-se de um assunto que extrapola seus limites.

Outro recurso desse mesmo tema foi discutido pelo Ministro Luiz Fux, relator do Recurso Extraordinário ARE 662.186/MG onde o recorrente sustenta que o exercício do poder de polícia de trânsito pode ser delegado à sociedade de economia mista. Em seu pronunciamento assim asseverou:

Assevera que a Lei Municipal 5.953/91 autorizou a criação da BHTRANS com a finalidade de controlar e executar os serviços de trânsito no Município de Belo Horizonte, consoante o disposto no art. 24 do Código de Trânsito Brasileiro (Lei 9.503/97), bem como no interesse público local, nos termos do art. 30 da CRFB. Já a recorrida alega que a BHTRANS tem apenas poder de polícia fiscalizatório, sendo vedada a imposição de sanções. Acrescenta que os agentes da recorrida são empregados celetistas, pertencentes à 
Administração Pública indireta e, portanto, incompetentes para o exercício do poder de polícia. Diante da relevância do tema sob o ponto de vista constitucional, uma vez que necessita de uma verificação da observância, por parte do município recorrente, dos limites impostos à delegação do exercício do poder de polícia, à luz do disposto no art. 24 do Código de Trânsito Brasileiro (Lei 9.503/97) e art. 30 da Constituição Federal. O referido ministro do STF assinala que como a questão constitucional em apreço ultrapassa os interesses das partes, avultando-se relevante do ponto de vista econômico, político, social e jurídico, submeteu a matéria aos demais ministros do STF. (BRASIL, 2012).

\section{O Recurso Extraordinário 662.186/MG (BRASIL, 2014) não admitiu a}

aplicação de sanção sobre o entendimento da inviabilidade da aplicação de multas da BHTRANS na qual declara ilegítima os autos de infração por ela elaborados.

RECURSO EXTRAORDINÁRIO COM AGRAVO. ADMINISTRATIVO. DIREITO CONSTITUCIONAL E ADMINISTRATIVO. APLICAÇÃO DE MULTA DE TRÂNSITO POR SOCIEDADE DE ECONOMIA MISTA. PODER DE POLÍCIA. DELEGAÇÃO DOS ATOS DE FISCALIZAÇÃO E SANÇÃO A PESSOA JURÍDICA DE DIREITO PRIVADO. AGRAVO PROVIDO PARA MELHOR EXAME DO RECURSO EXTRAORDINÁRIO. Decisão: Trata-se de agravo contra decisão que inadmitiu Recurso Extraordinário interposto com fundamento no artigo 102, III, "d", da Constituição da República, em face de acórdão proferido pelo Tribunal de Justiça do Estado de Minas Gerais, assim do: ação ordinária. Objeto. Declaração de ilegitimidade e restituição de multas de trânsito quitadas. Ilegitimidade da BHTRANS. Sociedade de economia mista. Impossibilidade. STJ. Procedência dos pedidos iniciais. Firmado, pelo Superior Tribunal de Justiça, o entendimento sobre a inviabilidade da BHTRANS, sociedade de economia mista, na aplicação de multas de trânsito, declara-se a ilegitimidade dos autos de infração elaborados e determina-se a restituição dos valores arrecadados pela entidade. Recurso não provido. "No recurso extraordinário, a recorrente argui ofensa aos artigos $5^{\circ}$, inciso XXXV, 30, incisos I e V, 37, cabeça e inciso XIX, e 175, da Carta da República. Para tanto, sustenta que o exercício do poder de polícia de trânsito pode ser delegado à sociedade de economia mista. Assevera que a Lei Municipal 5.953/91 autorizou a criação da BHTRANS com a finalidade de controlar e executar os serviços de trânsito no Município de Belo Horizonte, consoante o disposto no art. 24 do Código de Trânsito Brasileiro (Lei 9.503/97),bem como no interesse público local, nos termos do art. 30 da Constituição da República de 1988. Em contrarrazões, a recorrida alega que a BHTRANS tem apenas poder de polícia fiscalizatório, sendo vedada a imposição de sanções. Acrescenta que os agentes da recorrida são empregados celetistas, pertencentes à administração indireta e, portanto, incompetentes para 0 exercício do poder de polícia. 0 extraordinário não foi admitido na origem. Em sequência, a recorrente interpôs o presente agravo. Finalmente, por entender que o tema constitucional versado nestes autos é relevante do ponto de vista econômico, político, social e jurídico, além de ultrapassar os interesses subjetivos da causa, esta Corte reconheceu a repercussão geral do tema constitucional. É o Relatório. DECIDO. O agravo preenche todos os requisitos de admissibilidade, de modo que o seu conhecimento é medida que se impõe. Ex positis, PROVEJO o agravo e determino a conversão em recurso extraordinário para melhor exame da matéria. À Secretaria para a 
reautuação do feito. Publique-se. Brasília, 04 de setembro de 2014. Ministro Luiz Fux Relator Documento assinado digitalmente. (BRASIL, 2014).

Segundo Carvalho Filho (2010), existem situações em que há necessidade de o Poder Público exercer o poder de polícia na sua modalidade fiscalizatória. Assim, atribui a particulares, através de contratos, a fiscalização realizada através de máquinas, a exemplo dos aeroportos, onde é feita triagem para detectar se está sendo transportado algum proibido. No entanto, nessa situação não há delegação do poder de polícia, pois a tarefa executada pelo particular é apenas operacional.

Em respeito ao que foi analisado, verifica-se haver divergências entre a doutrina e a jurisprudência, no que tange a delegação do poder de polícia às entidades integrantes da Administração Pública indireta, especificamente às pessoas jurídicas de direito privado, afetando as empresas públicas, sociedades de economia mista e as fundações públicas com personalidade jurídica de direito privado. (ALEXANDRINO; PAULO, 2013).

À luz de outro cenário, podemos dizer que é pacífico o entendimento que cerca a delegação do poder de polícia às pessoas jurídicas de direito público da Administração Pública indireta, ou seja, as autarquias e fundações públicas com personalidade jurídica de direito público. Neste sentido Carvalho Filho diz:

Não é possível lhes atribuir, entretanto, a tarefa de editar leis, por exemplo, mas são permitidas as outras fases do ciclo de polícia, inclusive a aplicação de sanção de polícia, elucidam os autores. Outro fato contraditório surgiu quando da instituição da Guarda Municipal, sob a forma de empresa pública, pelo Município do Rio de Janeiro. A contratada era pessoa jurídica de direito privado e o quadro de servidores subordinados ao regime celetista. A discussão permeou a validade da aplicação de multas pela Guarda Municipal, uma vez que, por ser empresa pública, estaria impossibilitada de exercer o poder de polícia, restando nulas as multas efetivadas. No entanto, houve extinção da empresa pública através da lei Complementar no 100 do Município do Rio de Janeiro em 15 de outubro de 2009, e foi criada a Guarda Municipal sob a forma de autarquia. (CARVALHO FILHO, 2010).

Conforme entendimento de Scatolino e Trindade (2016), não há na CRFB dispositivo que vede o exercício do poder de polícia por pessoas jurídicas de direito privado, desde que sob a forma de fiscalização. $O$ art. 280 , $\S 4^{\circ}$ do CTB permite que a lavratura do auto de infração seja feita por policial militar ou servidor civil, seja 
estatutário ou celetista, tornando, portanto válidos seus atos fiscalizatórios. No mesmo sentido, atos de consentimento, sanção e regulação não podem ser delegados para pessoas jurídicas de direito privado. No que concerne a atos de fiscalização, estes poderão ser exercidos desde que o particular esteja habilitado para o exercício do poder de polícia na forma fiscalizatória. No entanto, os atos de consentimento do Estado, como licenças, deverão ser executados por pessoas jurídicas de direito público.

Para o exercício do poder de polícia por empresas públicas de direito privado, existem alguns requisitos que devem estar presentes, a pessoa jurídica deverá fazer parte da Administração Pública indireta; a delegação do exercício do poder de polícia deverá estar prevista em lei; por último o poder de polícia deverá ficar restrito a atos de fiscalização. (SCATOLINO; TRINDADE, 2016).

Ocorrem divergências também no que se refere à delegação do poder de polícia para as sociedades de economia mista e empresas públicas. Ambas as entidades possuem personalidade jurídica de direito privado e compõem a estrutura da Administração Pública indireta, bem como as prestadoras de serviços públicos. Entretanto, embora sejam pessoas jurídicas de direito privado, não são consideradas particulares. (MAFFINI, 2013).

O STJ por sua vez já se posicionou pela possibilidade de delegação da fiscalização e do consentimento de polícia para empresas públicas e sociedade de economia mista. No caso, a Corte reconheceu a possibilidade de exercício da fiscalização de trânsito, mas não a imposição de sanções, pela empresa de transporte e trânsito de Belo Horizonte (BHTRANS). (OLIVEIRA, 2018).

Quanto à aplicação de multa pela sociedade de economia mista, o autor esclarece que o STJ adota o entendimento da impossibilidade.

RE nOS EDcI no RECURSO ESPECIAL NO 817.534 - MG (2006/0025288-1)
RECORRENTE : EMPRESA DE TRANSPORTE E TRÂNSITO DE BELO
HORIZONTE - BHTRANS ADVOGADOS : CRISTIANO REIS GIULIANI
EDUARDO AUGUSTO VIEIRA DE CARVALHO E OUTRO (S) PROCURADORAS :
DAYSE MARIA ANDRADE ALENCAR MARIA DE FATIMA MESQUITA DE
ARAUJO RECORRIDO : MINISTÉRIO PÚBLICO FEDERAL PROCURADOR :
AURÉLIO VIRGÍLIO VEIGA RIOS DECISÃO Cuida-se de recurso
extraordinário interposto pela EMPRESA DE TRANSPORTES E TRÂNSITO DE
BELO HORIZONTE - BHTRANS, com fundamento no art. 102, inciso III, 
alínea a, da Constituição Federal, contra v. acórdão da e. Segunda Turma, cuja ementa ficou assim definida: "ADMINISTRATIVO. PODER DE POLÍCIA. TRÂNSITO. SANÇÃO PECUNIÁRIA APLICADA POR SOCIEDADE DE ECONOMIA MISTA. IMPOSSIBILIDADE. 1. Antes de adentrar o mérito da controvérsia, convém afastar a preliminar de conhecimento levantada pela parte recorrida. Embora o fundamento da origem tenha sido a lei local, não há dúvidas que a tese sustentada pelo recorrente em sede de especial (delegação de poder de polícia) é retirada, quando o assunto é trânsito, dos dispositivos do Código de Trânsito Brasileiro arrolados pelo recorrente (arts. 21 e 24), na medida em que estes artigos tratam da competência dos órgãos de trânsito. O enfrentamento da tese pela instância ordinária também tem por consequência o cumprimento do requisito do prequestionamento. 2 . No que tange ao mérito, convém assinalar que, em sentido amplo, poder de polícia pode ser conceituado como o dever estatal de limitar-se o exercício da propriedade e da liberdade em favor do interesse público. A controvérsia em debate é a possibilidade de exercício do poder de polícia por particulares (no caso, aplicação de multas de trânsito por sociedade de economia mista). 3. As atividades que envolvem a consecução do poder de polícia podem ser sumariamente divididas em quatro grupo, a saber: (i) legislação,(ii) consentimento, (iii) fiscalização e (iv) sanção. 4. No âmbito da limitação do exercício da propriedade e da liberdade no trânsito, esses grupos ficam bem definidos: O CTB estabelece normas genéricas e abstratas para a obtenção da Carteira Nacional de Habilitação (legislação); a emissão da carteira corporifica a vontade o Poder Público (consentimento); a Administração instala equipamentos eletrônicos para verificar se há respeito à velocidade estabelecida em lei (fiscalização); e também a Administração sanciona aquele que não guarda observância ao CTB (sanção). 5. Somente os atos relativos ao consentimento e à fiscalização são delegáveis, pois aqueles referentes à legislação e à sanção derivam do poder de coerção do Poder Público. 6. No que tange aos atos de sanção, o bom desenvolvimento por particulares estaria, inclusive, comprometido pela busca do lucro aplicação de multas para aumentar a arrecadação. 7. Recurso especial provido. (Fl. 559). Opostos embargos de declaração, o recurso integrativo foi parcialmente acolhido (fls. 608/620). Após defender a existência de repercussão geral das questões constitucionais discutidas no recurso, a recorrente alega em preliminar a violação pelo v. acórdão impugnado ao disposto nos arts. 50, inciso XXXV, 93, inciso IX, e 102, inciso III, alínea d, todos da Constituição Federal. Sustenta que, não obstante a oposição de embargos de declaração (itens 32 e 36 dos embargos), o e. ST] não teria se pronunciado sobre o fato de não haver particulares entre os acionistas da BHTRANS, configurando-se, assim, negativa de prestação jurisdicional. Ainda relacionado às preliminares, a recorrente diz que houve usurpação de competência por parte do e. STJ, eis que o e. Tribunal de Justiça do Estado de Minas Gerais teria julgado válida a delegação da atividade de controle de trânsito à BHTRANS com base em lei ordinária municipal, e conclui: "Ocorre que, a análise de compatibilidade (conflito) entre lei local e lei federal infraconstitucional, com todo o respeito, escapa ao âmbito de julgamento do Superior Tribunal de Justiça. Nos moldes em que dispõe o art. 102, III, 'd' da CF/88 (acrescido pela EC no 45/2004), tal competência é atribuída ao Supremo Tribunal Federal, em caráter exclusivo, em sede de recurso extraordinário. Nesse contexto, diante do julgamento levado a efeito na Corte de Minas Gerais - assentando a validade da lei local (Lei Municipal ${ }^{\circ}$ 5.953/91) - o conflito existente entre a lei Municipal contestada em face do Código de Trânsito Brasileiro (arts. 21 e 24) não poderia ser dirimido em sede de recurso especial." (Fls. 638/640). No mérito, a recorrente alega a violação pelo v. acórdão recorrido ao disposto nos arts. 30, incisos I e V, 37, 
caput e inciso XIX, e 175, todos da Constituição Federal. Aduz a possibilidade de delegação de execução de serviço público, aí incluída a atividade de controle de trânsito, à sociedade de economia mista e que essa delegação, operada pela via legal, consubstancia regular exercício da competência legislativa municipal. Contrarrazões às fls. 660/667. Decido. Presentes os pressupostos de admissibilidade, admito 0 recurso extraordinário. Remetam-se os autos ao c. Supremo Tribunal Federal. P. e I. Brasília (DF), 21 de outubro de 2010. MINISTRO FELIX FISCHER Vice-Presidente. (BRASIL, 2010).

\section{Em seu artigo Mezzomo (2014) nos diz que:}

Já no julgamento da cautelar da ADin no 2.310, o Supremo examinou a lei que trata dos agentes públicos de agências reguladoras (Lei no 9.985/2000), e ali se posicionou contrário à contratação de servidores em regime celetista. De acordo com o ministro Marco Aurélio, relator, prescindir, no caso, da ocupação de cargos públicos, com os direitos e garantias a eles inerentes, é adotar flexibilidade incompatível com a natureza dos serviços a serem prestados, igualizando os servidores das agências a prestadores de serviços subalternos, dos quais não se exige, até mesmo, escolaridade maior, como são serventes, artífices, mecanógrafos, entre outros. Atente-se para as espécies. Está-se diante de atividade na qual o poder de fiscalização, o poder de polícia fazem- se com envergadura ímpar, exigindo, por isso mesmo, que aquele que a desempenhe sinta-se seguro, atue sem receios outros, e isso pressupõe a ocupação de cargo público (...). Em suma, não se coaduna com os objetivos precípuos das agências reguladoras, verdadeiras autarquias, embora de caráter especial, a flexibilidade inerente aos empregos públicos, impondo-se a adoção da regra que é revelada pelo regime de cargo público, tal como ocorre em relação a outras atividades fiscalizadoras - fiscais do trabalho, de renda, servidores do Banco Central, dos Tribunais de Contas etc. (MEZZOMO, 2014).

\section{PROJETO DE LEI 280/2017 QUE AUTORIZA A DELEGAÇÂO AO PARTICULAR DO PODER DE POLİCIA}

Este Projeto de Lei busca estabelecer requisitos e diretrizes para que se possa delegar, no âmbito da Administração Pública Federal, o serviço de fiscalização administrativa por particulares. Trata-se da seguinte forma:

Art. $2^{\circ}$ Para os fins desta Lei considera-se:

I - delegação do serviço público de fiscalização administrativa a particular: transferência a pessoa jurídica não estatal, de direito privado, mediante autorização legal específica, do exercício de atividade de licenciamento, de vigilância ou sancionatória, mantida a titularidade estatal e preservado o regime jurídico de direito público, tendo em vista o interesse público disposto em lei;

II - poder delegante: a União, ou autarquia federal, sempre que promover a delegação do serviço público de fiscalização administrativa a particulares; 
III - agente delegado: pessoa jurídica não estatal, de direito privado, a quem seja delegado serviço público de fiscalização administrativa em setor específico;

IV - atividade de licenciamento: realização de processos administrativos e edição de atos administrativos, previstos em lei em razão do interesse público, destinados a expedir licenças, autorizações, certificações ou atos equivalentes, quanto a produtos, empreendimentos ou atividades;

$\mathrm{V}$ - atividade fiscalizatória: medidas que verifiquem a correta ou incorreta atuação daqueles que se submetem às normas legais ou regulamentares de regulação, em relação a fatos já ocorridos, sem espaço para juízo discricionário;

VI - atividade sancionatória: imposição de determinada consequência desfavorável, prevista em lei, a alguém em razão do cometimento de ilícito administrativo, sem espaço para juízo discricionário.

Entretanto, o art. 3 estabelece a vedação da delegação de serviço público de fiscalização administrativa a particular:

Art. 30 É vedada a delegação de serviço público de fiscalização administrativa a particular:

I - sem lei específica para cada setor, que autorize e fixe seus termos;

II - nas hipóteses em que lei expressamente houver previsto a indelegabilidade.

Parágrafo único. A edição de normas regulatórias ou técnicas sobre as atividades fiscalizadas é insuscetível de delegação a concessionária de serviço público de fiscalização, devendo sua adoção ficar a cargo da entidade delegante, nos termos da lei, podendo o agente delegado cooperar com as providências materiais e os estudos técnicos envolvidos.

Art. 40 Os atos do agente delegado, no exercício do serviço público de fiscalização administrativa, sujeitar-se-ão ao acompanhamento pelo poder delegante, com cooperação dos cidadãos.

Parágrafo único. A lei específica, o regulamento e, quando for o caso, os contratos de concessão estabelecerão os parâmetros de controle dos atos do agente delegado e as sanções a ele aplicáveis nos casos de desvio no exercício da delegação, cabendo ao regulamento e ao contrato estabelecer os indicadores para avaliação do desenvolvimento da atividade delegada.

De acordo com 0 art. $5^{\circ}$ do referido Projeto de Lei, o agente delegado deve adotar, no exercício do serviço público de fiscalização administrativa delegado, o devido processo administrativo, nos termos da Lei no 9.784, de 29 de janeiro de 1999.

Art. $5^{\circ} \mathrm{O}$ agente delegado deve adotar, no exercício do serviço público de fiscalização administrativa delegado, o devido processo administrativo, nos termos da Lei no 9.784, de 29 de janeiro de 1999.

$\S 1^{0} \mathrm{O}$ agente delegado deverá manter infraestrutura para receber e processar as reclamações dos cidadãos e decidir com imparcialidade e em tempo razoável.

$\S 2^{\circ}$ É garantido a todo cidadão o direito a contestar decisão de agente delegado, em recurso ao órgão ou entidade da Administração Pública encarregado da fiscalização de suas atividades.

Art. $6^{\circ}$ Ressalvados os casos em que a lei diretamente designe como agente delegado entidade de classe, ou atribua essa qualidade a todos os integrantes de categoria econômica ou profissional, a delegação do serviço público de fiscalização administrativa dependerá de contrato de concessão de serviço público, nos regimes de concessão comum, administrativa ou patrocinada, conforme o caso, e será precedida de licitação, nos termos da legislação própria e em que se observem os princípios da legalidade, impessoalidade, moralidade, publicidade, igualdade, do julgamento por critérios objetivos e da vinculação ao instrumento convocatório. 
Parágrafo único. O instrumento convocatório da licitação prevista no caput deverá fixar, de forma objetiva, os requisitos técnicos para participação no certame, os seus critérios de julgamento e a forma de remuneração do agente delegado.

Art. 70 Nos casos em que a delegação legal direta a entidade de classe ou a todos os integrantes de categoria econômica ou profissional autorizar o delegado a adotar normas técnicas a serem observadas pelos agentes sujeitos à sua fiscalização, o delegado terá o dever de observar os limites da lei e de assegurar, por meio de consulta ou audiência pública, oportunidade de participação aos potenciais interessados.

$\S 1^{\circ} \mathrm{A}$ adoção das normas técnicas será motivada, levando em consideração os argumentos e aspectos técnicos apontados pelos participantes da consulta ou audiência pública previstos no caput.

$\S 200$ controle administrativo e jurisdicional sobre decisão técnica de agente delegado incidirá sobre eventual desvio de finalidade, pelo exame da motivação técnica que a fundamentou.

Art. $8^{\circ} \mathrm{A}$ lei que autorizar a delegação a particular de serviço público de fiscalização administrativa deverá regular especificamente o processo administrativo correspondente, garantindo os princípios da ampla defesa e do contraditório.

Art. 90 O exercício de atividade sancionatória por agente delegado de serviço público de fiscalização administrativa tem caráter estritamente vinculado, em observância ao devido processo administrativo. $\S 1^{\circ} \mathrm{A}$ decisão do agente delegado em atividade sancionatória deverá ser motivada, apresentando o relato completo das ponderações de todos os envolvidos e a respectiva fundamentação técnica, embasada em razões de fato e de direito, que refute ou acolha tais manifestações. $\S 2^{\circ} \mathrm{Na}$ hipótese de resistência ao cumprimento de sanção, o agente delegado poderá requerer força policial.

Art. 10. Os agentes delegados, no exercício da delegação do de serviço público de fiscalização administrativa, responderão objetivamente pelos danos causados a terceiros, assegurado o direito de regresso contra 0 responsável nos casos de dolo ou culpa. Parágrafo único. O poder delegante tem responsabilidade subsidiária pelos danos previstos no caput.

Art. 11. O agente delegado subordina-se à legislação que regula o acesso dos cidadãos às informações públicas, particularmente à Lei no 12.527 , de 18 de novembro de 2011. (BRASIL, 2017).

Buscando maior eficiência e com o objetivo de dar possibilidades para que a Administração Pública possa contar com parceiros privados, no exercício do poder de fiscalização nos diversos setores estatais, o Excelentíssimo senador defende em sua página virtual que este projeto nos possibilitará ter mais fiscais, mais eficiência, e melhor prestação de serviço ao cidadão, vejamos:

O Senador Antônio Anastásia apresentou em 17 de agosto do ano de 2017 um Projeto de Lei (PLS 280/2017) que define diretrizes e requisitos para a delegação do serviço público de fiscalização administrativa a particulares.

Na prática, a proposta tem como objetivo possibilitar que a Administração Pública possa contar com parcerias privadas para exercer o poder de fiscalização nos mais diversos setores estatais. Para cada setor que o poder público prever a delegação será necessária lei específica. 
Sabemos que hoje há uma grande dificuldade para contratar e manter equipes de fiscalização nas mais diversas áreas. Por isso mesmo, alguns serviços públicos acabam sendo mal prestados. "Com esse projeto, por meio da parceria com o setor privado, poderemos ter mais fiscais, mais eficiência e melhor prestação de serviço ao cidadão", afirma Anastásia.

Com o Projeto de Lei, Anastásia pretende enfrentar o problema da falta de pessoal e da qualidade deficitária na fiscalização. Segundo o projeto, a empresa ou entidade que realizar a atividade por delegação da administração pública se sujeitará ao acompanhado pelo próprio Estado, com a cooperação dos cidadãos. Além disso, o contrato de concessão estabelecerá os parâmetros de controle dos atos da empresa e as sanções aplicáveis nos casos de desvio no exercício da delegação, cabendo ao regulamento e ao contrato estabelecer os indicadores para avaliação do desenvolvimento da atividade a ser delegada.

A decisão do agente delegado que determinar uma sanção, deverá ser motivada, apresentando o relato completo das ponderações de todos os envolvidos e a respectiva fundamentação técnica, embasada em razões de fato e de direito. Além disso, o agente delegado terá que manter infraestrutura para receber e processar as reclamações dos cidadãos e decidir com imparcialidade e em tempo razoável. A decisão do agente poderá ser contestada por qualquer cidadão perante a administração pública.

A administração pública tem muito a ganhar em termos de racionalização e eficiência com a regulação das possibilidades de delegação. Em uma área conexa, a prestação de serviços públicos, a participação da iniciativa privada, por meio dos institutos da permissão e da concessão, vem trazendo ganhos expressivos à sociedade, ao permitir uma expansão da capacidade de atuação do Estado. Acreditamos que, com a devida regulamentação, a delegação de fiscalização administrativa a particulares pode trazer "benefícios similares", afirma Anastásia. (BRASIL, 2017).

\section{CONSIDERAÇÕES FINAIS}

No decorrer deste trabalho foi especificado o conceito de poder de polícia administrativa, seus atributos e finalmente, a possibilidade de delegação.

Concluiu-se que as correntes doutrinárias não são favoráveis à delegação do poder de polícia a particulares. Isso porque a doutrina entende que essa delegação não é possível, quando há fins lucrativos.

De fato, pode-se afirmar que o poder de polícia é função típica do Estado, logo, atividade exclusiva, composta por um conjunto de atributos, que decorrem da própria essência estatal, na qual busca a paz e o bem-estar social, através da convivência em sociedade.

No tocante à possibilidade do exercício do poder de polícia por particulares, esta matéria já foi tratada pelo Supremo Tribunal Federal (STF) e consolidou-se o 
entendimento de que não é permitido transferir o exercício do poder de polícia para pessoas jurídicas que não integram a Administração Pública, diante das suas peculiaridades.

É importante frisar que o Projeto de Lei (PLS 280/2017) estabelece como exigência fundamental a necessidade de previsão em lei específica para a delegabilidade do serviço público de fiscalização administrativa no que diz respeito a cada setor específico, estabelecendo parâmetros gerais de controle dos atos do agente delegado. É necessário ainda que seja fixado, na lei específica, requisito de qualidade no desenvolvimento da atividade, bem como a obrigatoriedade de o agente delegado adotar o devido processo administrativo no exercício da atividade que the foi transferida.

Devido ao fato de não encontrar amparo, tanto na doutrina, como nos Tribunais, vislumbra-se que o Projeto de Lei 280/2017 não deva ser aprovado na CC] diante de sua latente inconstitucionalidade.

\section{REFERÊNCIAS}

ALEXANDRINO, Marcelo; PAULO, Vicente. Direito administrativo descomplicado. 21. ed. São Paulo: Método, 2013.

ASSESSORIA DE IMPRENSA DO SENADOR ANTONIO ANASTASIA. Buscando a melhoria dos serviços públicos, Anastasia apresenta projeto que prevê parceria privada para fiscalização. PSDB: MG, 17 ago. 2017. Disponível em: http://psdb-mg.org.br/noticias/buscando-a-melhoria-dos-servicos-publicos-anastasiaapresenta-projeto-que-preve-parceria-privada-para-fiscalizacao/. Acesso em: 8 nov. 2019.

BRASIL. Projeto de Lei do Senado $\mathbf{n}^{\circ} \mathbf{2 8 0}$, de 2017. Estabelece diretrizes e requisitos para a delegação, no âmbito da Administração Pública Federal, do serviço público de fiscalização administrativa a particulares. Autoria: Senador Antonio Anastasia (PSDB/MG). Brasília, DF: Congresso Nacional: Senado Federal, 2017. Disponível em:

https://legis.senado.leg.br/sdleg-getter/documento?dm=7108860\&ts=156752717455 2\&disposition=inline. Acesso em: 13 nov. 2019.

BRASIL. [Constituição (1988)]. Constituição da República Federativa do Brasil de 1988. Brasília, DF: Presidência da República, [2016]. Disponível em: http://www.planalto.gov.br/ccivil_03/constituicao/constituicaocompilado.htm. Acesso em: 20 jan. 2020. 
BRASIL. Lei no 5.172, de 25 de outubro de 1966. Dispõe sobre o Sistema Tributário Nacional e institui normas gerais de direito tributário aplicáveis à União, Estados e Municípios. Brasília, DF: Presidência da República, [1966]. Disponível em: http://www.planalto.gov.br/ccivil_03/leis/l5172.htm. Acesso em: 8 nov. 2019.

BRASIL. Supremo Tribunal Federal. Recurso Extraordinário nº 637.539/RJ.

Direito Administrativo e outras matérias de direito público. Recorrente: Município do Rio de Janeiro. Recorrido: Danielle Martins Ferreira Rezende. Relator: Min. Marco Aurélio, 23 de março de 2011. Disponível em:

http://portal.stf.jus.br/processos/detalhe.asp?incidente=4050609. Acesso em: 24 out. 2019.

BRASIL. Supremo Tribunal Federal. Recurso Extraordinário nº 662.186/MG. Direito Constitucional e Administrativo. Aplicação de multa de trânsito por sociedade de economia mista. Poder de polícia. Delegação dos atos de fiscalização e sanção a pessoa jurídica de Direito Privado. Recorrente: Empresa de Transportes e Trânsito de Belo Horizonte S/A - BHTRANS. Recorrido: Maria da Conceição Baltazar de Almeida. Relator: Min. Luiz Fux, 9 de março de 2012. Disponível:

http://redir.stf.jus.br/paginadorpub/paginador.jsp?docTP=TP\&docID=2741847. Acesso em: 26 out. 2019.

BRASIL. Supremo Tribunal Federal. Recurso Extraordinário com Agravo 662.186/MG. Recurso extraordinário com agravo. Administrativo. Aplicação de multa de trânsito por sociedade de economia mista. Poder de polícia. Delegação dos atos de fiscalização e sanção a pessoa jurídica de direito privado. Agravo provido para melhor exame do recurso extraordinário. Recorrente: Empresa de Transportes e Trânsito de Belo Horizonte S/A - BHTRANS. Recorrido: Maria da Conceição Baltazar de Almeida. Relator: Min. Luiz Fux, 4 de setembro de 2014. Disponível em: http://portal.stf.jus.br/processos/detalhe.asp?incidente=4162202. Acesso em: 26 out. 2019

BRASIL. Supremo Tribunal Federal. Recurso Extraordinário nos Embargos de Declaração no Recurso Especial no 817.534/MG. Administrativo. Poder de polícia. Trânsito. Sanção pecuniária aplicada por sociedade de economia mista. Impossibilidade. Recorrente: Empresa de Transportes e Trânsito de Belo Horizonte S/A - BHTRANS. Recorrido: Ministério Público Federal. Relator: Min. Felix Fischer, 28 de outubro de 2010. Disponível em: https://stj.jusbrasil.com.br/jurisprudencia/17016536/recurso-extraordinario-peticao-d e-recurso-especial-re-nos-edcl-no-resp-817534. Acesso em: 6 nov. 2019.

CARVALHO FILHO, José dos Santos. Manual de direito administrativo. 23. ed. Rio de Janeiro: Lumen Juris, 2010.

CARVALHO FILHO, José dos Santos. Manual de Direito Administrativo. 33. ed. São Paulo: Atlas, 2019. 
DI PIETRO, Maria Sylvia Zanella. Direito administrativo. 17. ed. São Paulo: Atlas, 2010.

DI PIETRO, Maria Sylvia Zanella. Direito administrativo. 32. ed. Rio de Janeiro: Forense, 2019.

JUSTEN FILHO, Marçal. Curso de direito administrativo. 10. ed. São Paulo: Revista dos Tribunais, 2014.

GONÇALVES, Leonardo de Mello. Limites da autoexecutoriedade do poder de polícia. São Paulo: Pontifícia Universidade Católica de São Paulo, 2010. Disponível em:

https://leto.pucsp.br/bitstream/handle/8980/1/Leonardo\%20de\%20Mello\%20Goncal ves.pdf. Acesso em: 19 mar. 2020.

MAFFINI, Rafael. Direito administrativo. 4. ed. São Paulo: Revista dos Tribunais, 2013.

MAZZA, Alexandre. Manual de direito administrativo. 9. ed. São Paulo: Saraiva Educação, 2019.

MEIRELLES, Hely Lopes; BURLE FILHO, José Emmanuel. Direito administrativo brasileiro. 42. ed. São Paulo: Malheiros, 2016.

MEZZOMO, Renato Ismael Ferreira. Transferência do poder de polícia às entidades privadas da Administração Pública segundo os Tribunais Superiores. Revista Jus Navigandi, Teresina, ano 19, n. 4053, 6 ago. 2014. Disponível em:

https://jus.com.br/artigos/29130/transferencia-do-poder-de-policia-as-entidades-priv adas-da-administracao-publica-segundo-os-tribunais-superiores. Acesso em: 8 nov. 2019.

MOREIRA NETO, Diogo de Figueiredo. Curso de direito administrativo: parte introdutória, parte geral e parte especial. 14. ed. Rio de Janeiro: Forense, 2005.

OLIVEIRA, Eduardo Antunes. 0 poder de polícia administrativa e a sua delegação. 2012. 73 f. Trabalho de Conclusão de Curso (Bacharelado em Ciências Jurídicas e Sociais) - Faculdade de Direito, Universidade Federal do Rio Grande do Sul, Porto Alegre, 2012. Disponível em:

https://www.lume.ufrgs.br/handle/10183/139430. Acesso em: 19 mar. 2020.

OLIVEIRA, Rafael Carvalho Rezende. Curso de Direito Administrativo. 6. ed. Rio de Janeiro: Forense, 2018.

ROSSI, Licínia. Manual de direito administrativo. 5. ed. São Paulo: Saraiva Educação, 2019. 
SCATOLINO, Gustavo; TRINDADE, João. Manual de direito administrativo. 4. ed. Salvador: Juspodivm, 2016. 